HID 40 (2013)

\title{
ARTESANOS ANTE LA JUSTICIA. LA ORGANIZACIÓN DE LA INDUSTRIA TEXTIL MEDIEVAL A TRAVÉS DE LA DOCUMENTACIÓN JUDICIAL: EL EJEMPLO CONTESTANO (1470-1492) ${ }^{1}$
}

\author{
ARTISANS BEFORE JUSTICE. \\ THE ORGANIZATION OF MEDIEVAL TEXTILE INDUSTRY THROUGH \\ JUDICIAL DOCUMENTATION: COCENTAINA (1470-1492)
}

\author{
JosÉ ANTONIO LliBrer EsCRIG \\ Univesitat de València \\ j.antonio.1librer@uv.es
}

RESUMEN: El trabajo analiza la documentación judicial (de la institución valenciana de la Cort de Justícia) con el objetivo de confirmar su idoneidad para conocer las formas de organización de la producción textil bajomedieval. Tomando como ejemplo Cocentaina, villa de clara vocación pañera, situada en la comarca valenciana del Comtat, mostramos cómo los registros del Justicia ofrecen abundante información sobre la organización manufacturera: aquí aparecen las compraventas de lanas, tintes y paños; también los encargos de trabajos textiles (tejido, tundido, tintado) que unos artesanos realizan a otros; incluso las compañías de capital a través de las cuales se asociaban estos artesanos y pañeros locales. Todo nos permite, en definitiva, reconstruir los tipos de empresa de estas comunidades artesanales y la jerarquización económica que se estableció entre ellas, dando lugar a un sector emprendedor que llegó a gestionar y coordinar buena parte de la producción pañera local.

PALABRAS Clave: Industria textil, especialización lanera, documentación judicial, siglo XV, artesanos emprendedores, País Valencià, Cocentaina.

ABSTRACT: This article studies the judicial documentation (from institution Cort de Justicia) with the aim of knowing the organization of textile production during the Later Middle Ages. In Cocentaina, small town of the Comtat region in southern Valencia, there was a woolen specialization, during 15th century. In this

1. El presente trabajo se integra en el proyecto de investigación "Identidades urbanas Corona de Aragón-Italia: redes económicas, estructuras institucionales, funciones políticas (siglos XIV-XV)", referencia HAR2011-28861, financiado por el Ministerio de Ciencia e Innovación (2012-2014), y dirigido por el prof. Paulino Iradiel Murugarren, catedrático del Dept. d'Història Medieval de la Universitat de València. Abreviaturas utilizadas: $\mathrm{AMC}=$ Arxiu Municipal de Cocentaina; $\mathrm{CJ}=$ Cort de Justícia. 
town, the judge papers -all the series of documents of the judge- provide profuse information about textile manufacture: in these documents we can see trading of wool, dyes and cloth; also we can see orders of textile works (weaving, shearing, dyeing); and we can see companies to manufacture and trade cloth between the artisans and local drapers. So we can study directly the artisans, their enterprises, their businesses, their investments, and their organization of the workshops. And finally we can see the role of enterprising artisans controling the purchase of raw materials, the infrastructure management and the sale of woolen cloth in regional markets.

KEYWORDS: Textile industry, wool specialization, judge papers, 15th century, enterprising artisans, Kingdom of Valencia, Cocentaina.

\section{LA FUENTE}

El 28 de septiembre de 1472, dos artesanos vecinos de Cocentaina, pequeña ciudad del interior valenciano, se presentan ante la Cort del Justícia de dicha villa: se trata del pelaire Joan Sanç y del tejedor de lana Joan Tolsa. Ambos denuncian ante el Justicia, cargo que ese año es desempeñado por Bartomeu Cirera, notario y mercader de la misma villa, el robo de dos paños que tenían depositados en el molino batán de Bernat Tequa, pelaire contestano. El alto valor de los paños - una palmella veintiuna, propiedad de Sanç, y un dieciocheno de Tolsa- lleva a ambos artesanos a interponer la denuncia, el clam, presentando incluso a dos vecinos como testigos de los hechos, el barbero Lluís Sanç y el pelaire Galcerà Pérez: posen clam de tots aquells que ls han furtat, robat e ab si portat, dos draps, ço és, una palmella vint-e-una, del dit en Johan Sanç, e hun dehuyté blanch del dit en Johan Tolsa, de la casa moli draper que és d'en Bernat Tequa, vehín de la dita vila ${ }^{2}$. Esta breve anotación, de sólo unas pocas líneas, incluida en uno de los volúmenes del Justicia de Cocentaina, nos aporta sin embargo una gran cantidad de información sobre las actividades artesanales y mercantiles de la villa y los agentes implicados: aparecen cuatro artesanos, tres pelaires y un tejedor; uno de los pelaires es el que regenta el molino pañero que ha sido asaltado por los ladrones ${ }^{3}$; aparece además un notario, Bartomeu Cirera, que es documentado también como

2. AMC, 46 / 11, Cort de Justícia, s/f. 1477, septiembre 28.

3. El detalle de que el pelaire sea el encargado de regentar y mantener el batán, como se indica con claridad en el documento, era un hecho nada extraño en la industria textil medieval peninsular, vid. P. IRADIEL. Evolución de la industria textil castellana en los siglos XIII-XVI. Factores de desarrollo, organización y costes de la producción manufacturera en Cuenca. Salamanca, Universidad de Salamanca, 1974, pp. 202-203. Y más recientemente, R. CÓRDOBA DE LA LLAVE. "Los batanes hidráulicos de la cuenca del Guadalquivir a fines de la Edad Media: explotación y equipamiento técnico", Anuario de Estudios Medievales 41/2 (2011), pp. 593-622. La capacidad de negocio de muchos pelaires emprendedores y la posibilidad de control, como veremos después, del proceso productivo así lo confirman. 
mercader en otros documentos y que desarrolla una intensa vida comercial ${ }^{4}$. El documento nos indica además los tipos de paños producidos en la villa y su nivel de calidad, estos paños de cuentas altas (de entre 18 y 21 centenares de hilos) son precisamente los predominantes en Cocentaina ${ }^{5}$. Las pocas líneas que forman esta anotación del escribano de la Cort del Justícia nos hablan además de la presencia de una de las instalaciones más importantes en todo el proceso de elaboración de la lana, el molino batán; el hecho mismo que los paños se encontrasen en esta instalación nos confirma la importancia que tenían estos procesos finales de refinición del producto en la industria textil contestana. Finalmente, una lectura aún más detallada del documento nos permite acercarnos a un último dato que puede ser fundamental: la actuación conjunta de los dos artesanos denunciantes puede hacernos intuir una relación profesional entre ambos $\mathrm{y}$, aunque el registro del funcionario municipal nada indica directamente de ello, el hecho que uno sea tejedor y el otro pelaire nos podría acercar a una posible asociación o complementariedad laboral. Veamos a este respecto un segundo ejemplo, con cronología cercana y similares protagonistas, e incluido también en la misma serie del Justicia local.

El 11 de marzo de 1479, Joan Pérez de Requena, poderoso y activo pelaire de Cocentaina, miembro de una de las familias más influyentes en la comunidad,

4. Hemos localizado a este notario-mercader vendiendo paños y productos agrícolas (cereales, vino, aceite). Para el análisis y el conocimiento de esta interesante comunidad pañera, como es la Cocentaina de la segunda mitad del siglo XV, nos hemos apoyado en la elaboración de amplios listados prosopográficos, en los que hemos cruzado una gran cantidad de información procedente de distintas fuentes -notariales, municipales, señoriales y las judiciales de las que ahora hablamos-. Ello nos ha permitido localizar sólo para esta villa un conjunto artesano-mercantil formado por casi 400 individuos, documentados y activos en un arco cronológico breve, entre los años 1470-1505. Hablamos, por ejemplo, de 183 pelaires en activo, 39 tejedores, 12 tundidores, 14 tintoreros, 39 sastres, 15 sederos, 20 drapers, 24 mercaderes y 10 artesanos del cuero. Cifras a todas luces significativas para una villa media como ésta. Los números superan, en la misma cronología, los de muchas ciudades del reino de tamaño parecido o incluso mayor como Xàtiva, Alzira, Castelló o Sogorb. Este análisis prosopográfico nos ha permitido además observar una evidente jerarquización económica en el seno del colectivo artesano mediante la diferenciación de un grupo más activo y emprendedor (que suponía alrededor del $12-15 \%$ del total), con empresas más solventes y negocios más diversificados, que tendían a controlar el acceso a las materias primas, a las infraestructuras (batanes, tintorerías, tiradores, almazaras), a la misma venta de los paños e incluso de otros productos. Además, junto al grupo cristiano, hemos localizado una activa comunidad islámica que mantiene estrechas relaciones artesano-mercantiles con sus vecinos cristianos, y que elevan nuestro análisis prosopográfico contestano a 495 individuos. Para más información sobre estos análisis prosopográficos y los operadores: J.A. LLIBRER. "La indústria tèxtil contestana al segle XV. Històries d'artesans i exercici prosopogràfic", Alberri 18 (2007), pp. 9-49; y sobre todo, J.A. LLIBRER. Industria textil y desarrollo regional: la Vall d'Albaida y el Comtat durante el siglo $X V$. Tesis doctoral inédita, Universitat de València, 2010, dirigida por Paulino Iradiel, vol. II, pp. 25-315.

5. Recordemos que la numeración del paño hacía referencia a los centenares de hilos que formaban su urdimbre: así, a cuentas más altas (pensemos en los paños 21 nos ó 24nos, de 2.100 y 2.400 hilos respectivamente) correspondían generalmente hilos más delgados, y como para un hilado más fino conviene lana más fina y selecta, la cuenta más alta en el paño implicaba mayor calidad y precio. Vid. P. IRADIEL. Evolución de la industria textil..., pp. 186-208. Sobre los tipos de paños producidos en Cocentaina, J.A. LLIBRER. Los orígenes de la industria de la lana en la Baja Edad Media. Valencia, Generalitat, 2007, pp. 74-87. 
y ahora Justicia municipal ${ }^{6}$, condena al también pelaire contestano Pere Cebrià, a pagarle al tundidor Bernat Ferrer, vecino de la misma villa, la cantidad de 10 sueldos y 6 dineros que le debía por unos trabajos de tundido de paños. En las escasas cinco líneas del registro judicial -éste es más breve incluso que el ejemplo anterior- se nos llega a indicar, además, que uno de los datos que se aportó en el juicio para confirmar la deuda fue precisamente el libro de cuentas del propio Cebrià: fonch condempnat per lo honrat en Johan Pérez de Requena, justícia de la dita villa, en donar e pagar a·n Bernat Ferrer, baxador, vehín de la mateixa villa, present, e instant, deu sous, sis diners de reals de València los quals en juhífonch vist que li devia de fahena de baxar, axi per lo libre de aquell com ab jurament que li fonch diferit ${ }^{7}$. De nuevo nos aparecen diversos artesanos: dos pelaires (uno de ellos, el propio Justicia, que con posterioridad será documentado como pañero o draper) y un tundidor o baxador, lo que ya nos denota la especialización profesional que se había concretado en el sector artesanal de la villa; el hecho incluso de que se nos hable, con toda normalidad, del uso de libros de contabilidad es además un importante síntoma de madurez artesanal y de clara conciencia de gestión empresarial. Pero sin duda, y éste es el dato más interesante, el documento nos remite a un tipo de relación socioproductiva cercana a los modelos protoindustriales, con la presencia de un artesano-emprendedor que organizaba su producción a través del trabajo por encargo y mediante la distribución de la materia prima o del producto semielaborado a otros artesanos asociados o subordinados, en una suerte de verlagssystem, aunque aquí relacionado más a un capital cuyo origen es el propio ámbito de la producción, y no a una capital de origen mercantil ajeno a la manufactura. Con posterioridad hablaremos de estas interesantes relaciones.

En la segunda mitad del siglo XV Cocentaina era una pequeña ciudad del interior-sur valenciano. Era el núcleo que regentaba un amplio espacio señorial, el Comtat, bajo dominio de los Corella, condes de Cocentaina desde 1448. En este período, la villa contaba con unos 550-600 fuegos, según los datos fiscales conservados $^{8}$. Ya desde el último cuarto del siglo XIV, y sobre todo a lo largo del $\mathrm{XV}$, se oberva un interesante crecimiento de sus actividades manufactureras en el sector de la lana, llegando a concentrar un amplio colectivo artesanal dedicado a este sector de varios centenares de artesanos, y sólo en la segunda mitad del Cuatrocientos, como demuestran nuestros análisis prosopográficos ${ }^{9}$. En todo este período estudiado, la industria textil contestana se nos muestra sin una reglamentación municipal o señorial que determine sus formas de producción. En efecto, no hay ningún tipo de regulación ordenancista ni tampoco existen veedores u otro tipo de oficiales públicos que ejerzan una evaluación o un control de los bienes

6. Sobre este destacado artesano y su influyente familia, vid. J.A. LLIBRER, "Històries d'artesans...”, pp. 9-49. E id. Industria textil y desarrollo regional..., vol. II, pp. 226-232.

7. AMC, 47 / 1, Cort de Justícia, s/f. 1479, marzo 11. Cocentaina. Sobre los artesanos, remitimos a nuestro análisis prosopográfico en J. A. LLIBRER. Industria textil y desarrollo regional..., vol. II, pp. 25-335.

8. E. GUINOT, “Senyoriu i reialenc al País Valencià a les darreries de l'època medieval”, Lluís de Santàngel i el seu temps, Valencia, Ajuntament, 1992, pp. 185-202.

9. Vid. nota 4, y J.A. LLIBRER. Industria textil y desarrollo regional..., vol II, pp. 25-335. 
producidos ${ }^{10}$. Así, en este contexto cercano a la libre empresa, que sin duda fue una de las causas de su desarrollo, lo que pretendemos ahora es mostar cómo la documentación judicial es esencial para conocer cómo funcionaba, desde su interior, esta importante actividad manufacturera en estas pequeñas ciudades o villas, cómo se organizaba su producción y qué relaciones generaba entre los distintos agentes implicados.

Y los dos ejemplos descritos anteriormente no son sino la confirmación de la importancia y la potencialidad de unas fuentes. Hemos ofrecido con detalle la aportación de los dos documentos para poder ver con claridad la riqueza de los registros contenidos en los libros del Justicia municipal, libros que por otra parte se han utilizado aún con escasa intensidad en las investigaciones de historia económica, a diferencia de lo que ha ocurrido en otros campos del análisis histórico.

Hace ya más de tres décadas, Bronislav Geremek llamó la atención sobre las posibilidades de estudio que ofrecían estos fondos. En las primeras páginas de su ya clásico trabajo sobre el artesanado parisino de los siglos XIII al XV, afirmaba que la documentación judicial se configuraba como "un groupe particulièrment précieux de sources, cal ils permettent de saisir sur le vif la practique effective, (...) nos montrent l'aspect humain, la forme quotidien des rapports sociaux"11. Desde esta evidente declaración de intenciones sobre la capacidad y el uso de estos registros, hasta los trabajos más recientes de M. Arnoux y J. Bottin, hay un largo trayecto historiográfico que nos muestra el aprovechamiento de los registros judiciales para el análisis de la manufactura medieval ${ }^{12}$.

En nuestro ámbito más cercano, tanto el que refiere al espacio peninsular como al estrictamente valenciano, ha habido pocos trabajos referidos al mundo artesanal que utilicen la documentación judicial. Deben destacarse, no obstante, las investigaciones de Germán Navarro, Joaquín Aparici y Josep Bordes, que reconstruyen procesos manufactureros y condiciones de vida artesanal con el auxilio de este tipo de registros ${ }^{13}$. Estos trabajos no hacen sino descubrir la riqueza "económica"

10. Situación frecuente para esta misma cronología en muchas pequeñas ciudades y villas de vocación manufacturera, vid. P. IRADIEL. "El mundo urbano. Propuestas y perspectivas de la investigación medieval", Millars. Espai i història 13 (1990), pp. 80-88; también id. "Ciudades, comercio y economía artesana", XXV Semana de Estudios Medievales, Pamplona, 1999, pp. 603-658.

11. B. GEREMEK. Le salariat dans l'artisanat parisien aux XIIIe-XVe siècles. Etude sur le marché de la main d'œuvre au Moyen Age. París, Muoton, 1982 (original 1968), p. 11.

12. M. ARNOUX, J. BOTTIN. "Les acteurs d'un processus industriel. Drapiers et ouvriers de la draperie entre Rouen et Paris (XIV-XVI siècle)", en M. ARNOUX, P. MONNET (dirs.) Le technicien dans la citté en Europe occidentale. 1250-1650. École Francaise de Rome, 2004, pp. 347-386, esp. pp. 351-354.

13. G. NAVARRO. El despegue de la industria sedera en la Valencia del siglo $X V$. Valencia, Generalitat, 1992; y también, G. NAVARRO. Los orígenes de la sedería valenciana. Siglos XV-XVI. Valencia, Ajuntament, 1999; J. APARICI. Producció manufacturera i comerç a Vila-real (1360-1529). Vila-real, Ajuntament, 1996. Id. El Alto Palancia como polo de desarrollo económico en el siglo XV: el sector de la manufactura textil. Segorbe, Ajuntament, 2001. Más recientemente, J. APARICI. "Materia prima para la manufactura. Su abastecimiento en Castelló a través de las actas del Justicia (1416-1450)", Millars. Espai i història 34 (2011), pp. 23-40. También P. IRADIEL et al. Oficios artesanales y comercio en Castelló de la Plana (1371-1527). Castelló, Fundació Dávalos-Fletcher, 1995. J. BORDES. 
de estas fuentes poco utilizadas aún para el análisis del mundo artesanal y de sus formas de organización.

Sin embargo, sobre el origen, las características jurídicas y las funciones de este oficial presente en los municipios valencianos existe ya una cierta bibliografía: desde los trabajos ya clásicos de Jesús Lalinde Abadía o Francisco Roca Traver $^{14}$, hasta los más recientes de Rafael Narbona, Antoni Furió o Pablo Pérez, que cubren el análisis de este oficial hasta bien entrado el periodo moderno ${ }^{15}$. Por otro lado, del privilegio de estudio de la ciudad de Valencia, se ha pasado al interés por analizar estas series documentales en numerosas ciudades y villas del reino: en efecto, más allá del ámbito de la capital, se conservan también importantes series de los libros de los justicias locales, que en algunas ocasiones se remontan al último tercio del siglo XIII, como es el caso de Alcoi o la misma Cocentaina. Y ante esta interesante oferta están apareciendo un conjunto de trabajos que permiten descubrir la polivalencia de estas fuentes ${ }^{16}$.

Nuestro trabajo pretende destacar la riqueza de estos registros para acceder al interior de la comunidad manufacturera, de los talleres artesanales, de las relaciones de producción que en ellos se generaban. Sin embargo, sería erróneo pensar que únicamente mediante estos libros judiciales podemos hacer un estudio completo de la industria textil, de la producción y de sus agentes; la documentación del Justicia, a pesar de su riqueza "económica", como hemos visto ya y como veremos

Desarrollo industrial textil y artesanado en Valencia. De la conquista a la crisis (1238-1350). Valencia, Consell Econòmic i Social, 2006.

14. J. LALINDE ABADÍA. "El "Curia" o "cort". (Una magistratura medieval mediterránea)", Anuario de Estudios Medievales 4 (1967), pp. 169-300. y F. ROCA TRAVER. El Justicia de Valencia, 1238-1321. Valencia, Ajuntament, 1970.

15. R. NARBONA. "El Justicia Criminal. Una corte medieval valenciana, un procedimiento judicial”, Estudis Castellonencs 3 (1986), pp. 289-310; R. NARBONA. Malhechores, violencia y justicia ciudadana en la Valencia bajomedieval. Valencia, Ajuntament, 1990. A. FURIÓ. "Crédit, endettement et justicie: prêteurs et débiteurs devant le juge dans le royaume de Valence (XIII-XV siècle)", en J. CLAUSTRE (dir.) La dette et le juge. París, 2006, pp. 19-53. También P. PÉREZ. El Justicia criminal de Valencia (1479-1707). Una magistratura urbana valenciana ante la consolidación del Absolutismo. Valencia, Generalitat, 1991, esp. pp. 30-64.

16. La cita de títulos sería muy extensa, ofrecemos sólo una pequeña muestra sobre diferentes temas y villas. A. FURIÓ. "Entre la complémentarieté et la dépendence: rôle économique et travail des femmes et des enfants dans le monde rural valencien au bas Moyen Âge", Médiévales 30 (1996), pp. 23-34. A. FURIÓ. "Endettement paysan et crédit dans la Péninsule Ibérique au Bas Moyen Âge", en M. BERTHE (ed.) Endettement paysan et crédit rural dans l'Europe médiévale et moderne, XVII Journées Internationales d'Histoire de l'Abbaye de Flaran, Toulouse, 1998, pp. 139-167, esp. 145-146 y 152-153. También A. FURIÓ, "Crédit, endettement et justicie..., pp. 19-30; y J.V. GARCÍA MARSILLA. Vivir a crédito en la Valencia medieval. De los orígenes del sistema censal al endeudamiento del municipio, Valencia, PUV, 2002, esp. pp. 76-83. Y en concreto, sobre algunas villas del sur, aunque en diversa cronología: J. TORRÓ. La formación d'un espai feudal. Alcoi de 1245 a 1305 . València, Centre d'Estudis d'Història Local, 1992; C. FERRAGUD. El naixement d'una vila rural valenciana. Cocentaina, 1245-1304. València, PUV, 2003; M.D. INSA. "La justicia municipal en el Condado de Cocentaina durante el siglo XVI: problemas jurisdiccionales", La ciudad hispánica durante los siglos XIII-XVI. Madrid, 1985, pp. 1645-1659. E. GUINOT. "Sobre l'activitat de la justícia a un menut poble valencià d'inicis del segle XV: Xixona (1413)", Anales de la Universidad de Alicante-Historia Medieval 10 (1995), pp. 63-80; J.A. BARRIO. "Lo marginal y lo público en Orihuela a través de la acción punitiva del Justicia Criminal, 1416-1458", Idem, pp. 81-98. 
a continuación, necesita sin duda la complementariedad de otras fuentes, tanto públicas como privadas ${ }^{17}$. Complementariedad y combinación heurística que permita la elaboración de análisis prosopográficos para el seguimiento y la catalogación de individuos, empresas y negocios. El trabajo que ahora presentamos no deja de ser un ejercicio sobre el interés y la idoneidad de la documentación judicial pero que tiene como base un amplio desarrollo prosopográfico.

\section{LOS NEGOCIOS Y SU REFLEJO EN LA FUENTE}

Recordemos en primer lugar que, en el ámbito del País Valenciano, la Cort del Justicia era una institución presente en todas las ciudades y villas, materializada a través de un oficial electo anualmente por la propia comunidad y que concentraba buena parte del poder ejecutivo. Este oficial actuaba como juez de primera instancia en ámbito local para todo el amplio conjunto de pleitos y conflictos civiles en los que podían verse implicados sus vecinos, y además intervenía en todas las decisiones importantes que afectaban a la comunidad ${ }^{18}$. Este juez local era asesorado por los jurados y consellers en cuestiones más delicadas que pudieran afectar al desarrollo de la villa, llegando todos a formar una especie de tribunal donde el Justicia tenía la máxima autoridad. La Cort del Justícia se reunía todos los días del año, excepto festivos, para solucionar los problemas que planteaba el ritmo de la vida y las actividades de los vecinos. Por ella pasaban agricultores que denunciaban a ganaderos por la invasión de sus parcelas, artesanos que reclamaban deudas, mercaderes o pañeros que exigían el pago de todo tipo de productos (cereales, aceite, vino, pero también lana, tejidos, tintes...), y a ella llegaban cartas de otros justicias o funcionarios de ciudades vecinas que exigían detenciones, pagos o embargos; a su vez, el Justicia local enviaba misivas a otros para requerir estas mismas exigencias.

Toda esta frenética actividad hacía necesaria la presencia alrededor de esta corte judicial de toda una serie de oficiales que permitían el funcionamiento ágil y fluido de la maquinaria legal y que además garantizaban el cumplimiento de las sentencias: los mismos jurados locales, los notarios o escribanos municipales, los

17. En nuestro caso hablamos de la documentación notarial -sorprendentemente abundante para esta villa en la segunda mitad del siglo XV, y que en el fondo es sinónimo de su intensa actividad económica-, las actas municipales de los Manuals de Consell, e incluso la documentación señorial que ha generado la administración del mismo condado de Cocentaina. Sobre las fuentes para esta villa, J.A. LLIBRER. Industria textil y desarrollo regional..., vol. II, pp. 340-533.

18. Vid. R. NARBONA. Malhechores, violencia..., pp. 31-42. Sobre el origen, formación y elección de este oficial, A. FURIÓ. "Crédit, endettement et justicie..., pp. 27-30. En el caso de Cocentaina, centro de jurisdicción señorial en esta cronología, la situación es similar a la de las villas reales, por el hecho de que durante largos periodos del siglo XIII al XV había pertenecido a la Corona. Así, la comunidad intentará mantener tales derechos a pesar de que con la adquisición del condado por parte de Ximén Pérez de Corella en 1445, se le concede a éste la jurisdicción civil y criminal. Dicha situación no dejará de generar conflictos entre la villa y su titular, vid. M.D. INSA, "La justicia municipal..., pp. 1650-1659, aunque en nada afectará al ritmo cotidiano de su actuación. 
guardianes que informaban al Justicia de distintos hechos delictivos, los corredores que localizaban a los implicados o a los posibles culpables, los evaluadores que ponían precio a los bienes de futuros embargos... Pero lo interesante en nuestro caso contestano es que en todos estos cargos estaban presentes con mucha frecuencia los artesanos del textil, es decir, pelaires, tundidores, tintoreros o pañeros, que durante muchos años llegaron casi a monopolizar estas responsabilidades; eran ellos mismos, en efecto, los que habían sido elegidos para estas funciones y estos cargos municipales (desde la misma magistratura judicial hasta las responsabilidades menores de corredores, vigilantes o guardines del término), tal vez en un intento de llegar a gestionar esta compleja institución para defender mejor sus cada vez mayores intereses industriales. No hay duda que el control del aparato judicial suponía para el colectivo artesanal un instrumento básico para la consolidación de las actividades pañeras frente a otros intereses -agrícolas, esencialmente-como se había ido demostrando en la misma villa de Cocentaina desde el último tercio del siglo XIV, cuando la manufactura lanera comienzó a implicar un sector cada vez mayor de su economía local ${ }^{19}$.

Estudiemos ahora con detalle las posibilidades que nos aportan los libros judiciales para el estudio directo de las actividades artesanales. Todos los volúmenes de la Cort del Justícia de Cocentaina que hemos analizado tienen la misma estructura compositiva según la tipología de asuntos judiciales tratados ${ }^{20}$. La ligazón posterior de los libros por parte del escribano o del notario hace que el orden de los bloques documentales, que comentaremos a continuación, siempre se mantenga. Así, tres son las grandes tipologías documentales que se repiten en cada volumen:

\subsection{Condenas y obligaciones}

Las condenas forman un conjunto de sentencias del Justicia, generalmente breves -de no más de cinco líneas-, sobre la acusación realizada por algún vecino. Este conjunto es la denominada Mà de condempnacions e obligacions de pena del quart. Bajo el encabezado, donde se consignaba la fecha, los distintos escribanos iban anotando, en forma de pequeños asientos, las acusaciones y las penas impuestas por el titular de la Cort, conformando así un libro registro, un dietario,

19. Así se ha comprobado mediante el estudio de las órdenes o establiments que se fueron aprobando en la villa desde la década de 1370 -y que se incluyen en los mismos libros del Justicia-, en los que se favorece a los intereses de la manufactura pañera (de los grandes propietarios de ganado lanar, con frecuencia también importantes artesanos o pañeros locales) frente a los intereses del sector agrícola. En adelante explicaremos con mayor detalle este interesante proceso. Sobre estas órdenes, J.A. ALABAU. "Els establiment locals com a instrument de control econòmic i social de les viles medievals valencianes. Cocentaina a la darreria del segle XIV”, Afers 47 (2004), pp. 175-187.

20. Para esta investigación hemos estudiado la información de todos los registros conservados en el Archivo Municipal de Cocentaina que corresponden a la segunda mitad del siglo XV, lo que supone un total de 10 libros. Los correspondientes a los años: 1470, 1471, 1472, 1476, 1478, 1479, 1481, 1488, 1489 y 1492. AMC, CJ, Signaturas 45/1 a 48/2. A partir del volumen de 1478, la conservación de los libros no es completa; encontramos diversos saltos en diferentes secciones. Por ello, para realizar los cálculos estadísticos posteriores, utilizaremos solamente los libros que se han conservado completos, en un intento de evitar posibles distorsiones. 
un largo inventario anual con los requerimientos y actuaciones a instancias de particulares. Tras escuchar a ambas partes, a sus asesores, o tras el análisis de las pruebas presentadas, las condenas se traducían siempre en una multa en metálico (de cuyas cantidades hablaremos a continuación), lo que confirma la tendencia, ya documentada en otros ámbitos, a monetizar al máximo la acción judicial en aras de conseguir una mayor efectividad de la recaudación ${ }^{21}$. Sólo otro ejemplo interesante: En Berthomeu Cirera, justícia de la vila de Cocentayna, stant en juhí, a consell de son assesor ordinari, instant e requirent en Bernat Jover, condempna a.n $\mathrm{Ni}$ cholau Boraç, vehín de la dita vila, en retre e restituir a aquell sis sous huyt diners per la part aquell tocant a restituir de aquella llana que prengué del bestiar del dit en Jover com arrendadors ${ }^{22}$. Con frecuencia, las pruebas presentadas por alguna de las partes eran albaranes o libros de contabilidad redactados directamente por los propios artesanos o mercaderes, porque, recordemos, en las ventas a crédito o al fiado, la inscripción en los libros privados tenía validez legal ${ }^{23}$.

Por otro lado, las cuantías de las multas podían llegar a ser elevadas (iban, en los registros que hemos analizado, desde un mínimo de 1 sueldo y 4 dineros, hasta un máximo de 590 sueldos); y precisamente, como veremos después, las multas más elevadas correspondían generalmente a productos relacionados con la manufactura textil: lana, paños, productos para el tinte, o al mismo tintado de paños. En muy pocas ocasiones el Justicia impone como pena el pago en especie, sólo en un $3 \%$ de los registros documentados, lo que permite confirmar la idea antes expresada de una clara tendencia a monetizar la acción judicial. Incluso en aquellos pocos casos en los que el Justicia impone una pena en forma de trabajo o de algún tipo de operación -y aquí son mayoría las operaciones textiles-, traduce además en metálico el valor de dicho trabajo: Lo honorable justícia, stant en juhí more solito, instant e requirent en Jacme Duran, perayre, ex confessione, condempna a Johan de Gàlbiz, texidor de draps de llana, present, en texir aquell hun drap dihuyté o pagar aquell $X$ sous $^{24}$. Junto al interesante dato económico sobre el posible coste

21. Esta tendencia es observada ya en una cronología anterior por R. NARBONA. Malhechores, violencia..., pp. 31-42.

22. AMC, CJ 45/2, 1472-I-26. Gracias a nuestros análisis prospográficos, sabemos que Bernat Jover es mercader, y Nicolau Borràs un activo draper, que durante años fue corredor de la misma Cort de Justícia.

23. La leyes forales admitían como prueba la inscripción de una deuda en los libros contables de los cambistas o de cualquier otro profesional, vid. J.V. GARCÍA MARSILLA. Vivir a crédito..., pp. 73-75. Las referencias a albaranes o libros de contabilidad privada son constantes en Cocentaina, y tanto en la documentación judicial como en la notarial. Sólo algún ejemplo significativo: Lo justícia, stant en juhi [...] instant e requirent en Thomàs Vayello, procurador de Pasqual Monleó, en virtut de un albarà scrit de mà del dit en Johan de Torres [pelaire vecino de Cocentaina] deutor, [...] lo qual és del tenor següent: "Yo Johan de Torres confés deure a vós en Pasqual de Monleó, és a saber, XX sous, los quals vós me haveu prestat e perquè és veritat faç vos lo present albarà scrit de má mia”, AMC, CJ 45/1, 1470-V-24. En Nicholau Borraç, draper vehín de la vila de Cocentayna, ex confessione, fon condempnat per lo justícia de dita vila en donar e pagar a $n$ Alfonso de León, tintorer, vehín de la dita vila, cinquanta sous de reals de València, los quals li confessa deure de resta de tintes, segons consta per albarà en libre del dit en Alfonso de Leon... AMC, CJ 45/1, 1471-VII-20.

24. AMC, CJ 45/2, 1472-X-30. Por nuestro análisis prosopográfico sabemos que ambos artesanos son vecinos de Cocentaina. Vid. J.A. LLIBRER. Industria textil y desarrollo regional..., vol. II, pp. 111-112 y 138 . 
de la operación del tejido de un paño amplio y de calidad, dieciocheno, el documento nos remite de nuevo a una organización protoindustrial de la producción textil, de la que después nos ocuparemos.

Junto a las condenas encontramos con frecuencia en esta misma serie las llamadas "obligaciones". Se trata de un conjunto de registros de deuda. Mediante estos breves asientos, un deudor se obligaba a pagar a otro vecino una deuda previamente acordada: en Domingo Bernat, perayre, vehín de la vila de Cocentayna, voluntàriament e de grat, se obliga en donar e pagar a·n Alfonso de León, tintorer, cinquanta sous de reals de València, los quals li devia de tintes de un drap que li tenyí negre ${ }^{25}$. La obligació consistía así en un reconocimiento de deuda -o de venta a crédito o a plazos- por el cual el deudor se comprometía ante el Justicia a pagar al acreedor el crédito o el precio de los bienes adquiridos o de servicios realizados; si se producía algún retraso éste era denunciado y el juez daba un plazo para el pago, tras el cual, si persistía la deuda, incurría en la pena del quart. Este sistema permitía acordar una adquisición a crédito o a plazos sin necesidad de pasar por el notario y evitando así los gastos que éste exigía; sin duda tal ahorro para ambas partes era la causa que explica la multiplicación de estos asientos en los libros del justicia local ${ }^{26}$.

Tanto en la forma condenatoria como en la obligativa, se configuraba en esta primera parte de los libros del Justicia un amplio inventario de entradas documentales en unas pocas líneas donde se registraban numerosísimas actividades, compraventas y negocios, pero donde también aparecían los agentes económicos: artesanos, mercaderes, agricultores, ganaderos... En definitiva, un conjunto plenamente aprovechable para la reconstrucción socioeconómica de una comunidad, y sobre todo para comunidades de tamaño medio, como la Cocentaina del siglo XV, donde es más fácil el seguimiento de oficios, talleres, empresas...

Así, encontramos deudas que refieren lógicamente a actividades agrícolas: deudas de productos como cereales, aceite, vino, frutas... También aparecen numerosas referencias a la potencialidad ganadera de la zona: deudas por todo tipo de ganado, sobre todo, ovejas, cabras y también bestiar en general, así como animales de tiro (mul, ase, somera, rocí...). El reflejo de un importante y activo mercado inmobiliario está también presente (deudas por compra o arrendamiento de casas, huertos, parcelas, almazaras...). De la misma forma, el activo mercado de capitales ocupa una parte importante de los registros: deudas por préstamos directos o de interés no declarado - préstec graciós- o por pensiones de crédito censal, o por fianzas -fermances-en compraventas, cesiones, permutas, etc. Todo ello nos permite observar la importancia y el papel del sector artesanal y mercantil en la economía local, su función como importantes acreedores, pero también como redistribuidores de bienes de consumo y capitales.

25. AMC, CJ 46/2, 1478-III-15.

26. Sobre el funcionamiento de este sistema inicial de crédito, vid. H. GARCÍA SANZ. "La obligación”, Boletín de la Sociedad Castellonense de Cultura 11 (1930), pp. 22-27. Vid. el análisis que de estos registros realiza A. FURIÓ. "Endettement paysan..., esp. 145-146 y 152-153. y J.V. GARCÍA MARSILLA. Vivir a crédito..., pp. 76-83. 
Pero son los registros relacionados lógicamente con la producción artesanal los que nos van a permitir el acercamiento directo a la organización de una manufactura en crecimiento: en estas series encontramos deudas por todo tipo de materias primas (aunque con el claro predominio de la lana, también aparece la seda, el lino, el cáñamo o el cuero) y productos para el tinte (pastel, gauda, roja). Las deudas por paños son sin duda, como confirmaremos después, una de las más numerosas en todos los volúmenes consultados: predominan los paños de calidad “dieciochenos" y "veintiunos". De la misma forma encontramos también impagos por prendas de vestir, lo que nos permite entrar en el ámbito de la sastrería (camisses, capes, gonelles, calces $)^{27}$. Pero allí donde mejor se manifiesta la organización de la producción es en las deudas por distintas operaciones del amplio proceso textil: así, encontramos deudas por el tejido de paños (per teixidures), por el tintado (per tintures, per tenyir draps), por el tundido (per fahena de baxar) e incluso por la confección (per costures) $)^{28}$. Estamos sin duda, ante claras formas precapitalistas de trabajo por encargo: un artesano, generalmente un activo pelaire o pañero local, encarga a otro alguna de estas operaciones, lo que comienza a manifestarnos el papel de algunos de estos agentes locales -que bien podemos llamar artesanos emprendedores; auténticos verlegers, si seguimos el modelo protoindustrial-en la gestión y la coordinación de buena parte de la pañería local mediante el control, como veremos después, del mercado de materias primas (lanas, tintes, aceite), de los procesos de acabado del paño (tintado, tundido, abatanado) y de la comercialización de los mismos paños en los mercados comarcales.

Por otra parte, junto a las ya comentadas deudas por lana, paños, tintes y todo tipo de operaciones textiles, también encontramos algunos asientos que hacen referencia a problemas con la contabilidad de compañías artesanomercantiles. Los socios -artesanos, pañeros o mercaderes contestanos- acuden al Justicia para dirimir los problemas que plantea la contabilidad de tales compañías, lo que nos permite de nuevo ver estrategias, formas de negocio y de asociación artesanal. Por ejemplo, en septiembre de 1470, ante los problemas constantes que estaba

27. Recordemos que hemos documentado en la villa un amplio número de sastres -39- para esta cronología ajustada (1470-1505), que lógicamente hay que asociar a la importante producción pañera de este pequeño burgo.

28. Para conocer directamente esta riqueza de la fuente, su diversificada tipología y su frecuencia-sinónimo del desarrollo textil contestano-, ofrecemos unos pocos ejemplos que hemos localizado en un solo volumen, el de 1470: En Johan Siurana, perayre vehín de Cocentayna, fonch condempnat per lo dit honrat Justicia de la dita vila en donar e pagar a $n$ Johan de Bas, texidor, present e instant, set sous, los quals atorga en juhi que li devia de texidures (1470-I-26). Lo honrat en Bernat Botet, justicia, instant e requirent en Pere Loppez d'Alcaraç, texidor de draps de llana, ex confessione, condempna a $n$ Bernat Nogueroles, perayre de la dita vila, cinch sous, quatre diners, los quals fonch vist li devia de texidures de hun drap que aquell li havia texit (1470-VI-1). En Johan Navarro, perayre vehín de la vila de Cocentayna, fonch condempnat per lo honrat en Bernat Botet, justícia de la dita vila, en donar e pagar a.n Pere Maroquí, tintorer, vehi de la mateixa vila, present e instant, sexanta sous de reyals de València, per tintes de una bruneta diuhitena que atorga haver-li tenyida (1470-XII-12). Lo honrat en Nicholau Calbet, justicia de la vila de Cocentayna, instant e requirent en Anthoni Sanç, vehín de la dita vila, condempna a'n Johan Celler, perayre de la mateixa vila, ex confessione, en donar e pagar aquell, sexanta-cinch sous de reyals de València, los quals li atorga deure per tintes que aquell fetes li havia de resta de dos draps, la hun vert e l'altre blau (1471-VII-18). 
generando la contabilidad de una compañía pañera (así se denomina en la propia documentación, companyia de draperia) suscrita entre Antoni Sanç, draper, y Alfonso de León, tintorero, el Justicia nombra a dos jueces para que, estudiadas las pruebas y escuchadas las partes, decidan sobre sus cuentas ${ }^{29}$. Otro ejemplo destacado lo encontramos poco tiempo después: el Justicia condena al tintorero contestano Pere Maroquí a pagar 29 libras, 10 sueldos y 7 dineros por deudas pendientes de la compañía para el tintado de paños y la adquisición de los costosos productos tintóreos, suscrita entre el mismo Maroquí y su cuñado Antoni Sanç -el draper anterior-, de tot lo temps de la companyia que feta han del tint, tro a la present jornada, de pastells, alums, roges, gaudes, lenya e altres tintes menudes necessàries al dit tint ${ }^{30}$.

Más allá de estas interesantes citas, sobre las que después volveremos, un mínino estudio estadístico de la información que aportan todas las deudas nos permite reconocer el potencial productivo de esta comunidad artesanal que es la Cocentaina del siglo XV. La actividad textil lanera es la causa que genera el mayor número de acusaciones registradas, por delante incluso de las actividades agrarias. De las casi 500 acusaciones o condenas analizadas -en total 462-, el $35 \%$ han sido generadas por deudas relacionadas con la manufactura de la lana: materias primas, ganado lanar, paños, ropa, pero también las operaciones textiles comentadas antes -teixidures, tintures, costures ${ }^{-31}$. Sin embargo, los registros generados por deudas agrícolas suponen solamente un $23 \%$ (ventas de cereales, aceite, vino, animales de tiro o ganado no lanar). El resto de acusaciones está relacionado con el mercado de capitales (deudas por pensiones de censal, préstamos directos, dites, cesiones, garantías, etc.) que supone el $20 \%$ de los registros, y finalmente el mercado inmobiliario rural y urbano, que da lugar al 11,25\% de las deudas. No obstante, en ambos "mercados", tanto el del crédito como el inmobiliario, el protagonismo del colectivo artesanal y mercantil es, como veremos ahora, acaparador.

A su vez, si concretamos dentro de los grupos anteriores de deudas, podemos comprobar que las acusaciones por paños o ropa son las más numerosas (el 15,36 \%): en ellas encontramos siempre a los más activos pelaires y drapers solicitando a sus vecinos el pago de estas deudas textiles ${ }^{32}$. En segundo lugar nos aparecen las deudas por distintos productos agrícolas $(11,47 \%)$, sobre todo cereales y aceite, pero

29. Delegam e assignam vosaltres, en Francesch Rotlan e en Bernat de Mataredona, notari, vehïns de dita vila, en jutges comptadors, decisors, hoydors, e per fin leguda determinadors, de la causa, qüestió e contrast de comptes que:s mena e menar s'espera, entre en Alfonso de Leon, tintorer, de una part, compte demanant, e en Anthoni Sanç, draper, de la part altra, compte volent retre, per rahó de la companyia de draperia e altres coses que entre aquells és estada (AMC, 45 / 1, CJ, 1470-IX-13).

30. AMC, 47 / 2, CJ, 1481-IV-14. Sobre estas interesantes compañías para el tintado y el suministro de productos tintóreos, vid. J.A. LLIBRER. "La formación de compañías para el tintado de paños. El caso de Cocentaina en el siglo XV", Anuario de Estudios Medievales 41/1 (2011), pp. 59-72.

31. Conviene recordar que en los siguientes cálculos estadísticos no hemos podido utilizar todos los libros del Justicia a causa de su fragmentada conservación. Aunque disponemos de una mayor cantidad de registros, hemos preferido no contabilizarlos para evitar distorsiones en los resultados.

32. De este $15,36 \%$, la mayoría son deudas lógicamente por paños (el $85 \%$ ), el resto por distintas prendas (calces, gonella, capa, camissa) o por la denominación genérica de certa roba. 
también vino y frutas (cireres, nous...) en menor porcentaje ${ }^{33}$. Pero tal vez lo que más llama la atención en la villa de Cocentaina es la gran cantidad de deudas (más del $10 \%$ ) que tienen como origen distintas operaciones textiles (las ya comentadas de tejido, tintado, tundido) porque nos confirman con claridad la importancia y el peso que las actividades manufactureras habían adquirido ya en la economía local. Una actividad industrial gestionada por un sector artesanal y mercantil muy sólido, un sector "emprendedor" que dominaba las infraestructuras textiles y sus materias primas, que generaba todo tipo de asociaciones o compañías de capital, pero que también participaba activa y favorablemente en el mercado inmobiliario, en el del crédito censal, en los préstamos usurarios, y en todo tipo de transacciones hasta hacerse omnipresente en los negocios locales y comarcales, como informan los libros del Justicia y los protocolos notariales. Los análisis prosopográficos ilustran con claridad esta omnipresencia económica.

\section{2. "Lletres missives"}

La segunda serie documental que aparece en los libros del Justicia es el bloque formado por el conjunto de cartas enviadas por este oficial a otros de otras villas para reclamar el pago de deudas. En el caso contestano, desde el punto de vista tipológico, la copia de la carta enviada se encabezaba siempre con las partes implicadas, lo que nos aporta ya un conjunto interesante de agentes y hombres de negocio, tanto de Cocentaina como de otras villas que mantenían relaciones con el sector más dinámico de la capital del Comtat: Jaume de Pujaçons, notari, en cert nom, contra Berthomeu Ager de Alcoy. A continuación, tras la fecha se iniciaba el contenido de la misiva: A l'honrat lo justícia de la vila de Alcoy o a son lochtinent, de nós, en Johan Pérez de Requena, justícia de la vila de Cocentaina, saluts e honor. Instant e requirent Jaume de Pujaçons, scrivent, en nom de procurador de l'honrat en Bernat Martí, draper, nostre vehí, habitant en la ciutat de Xàtiva. Se indicaba posteriormente la causa del documento, es decir, la actuación que se solicitaba del Justicia de la otra villa, y la deuda que la había generado: pregam que en loch nostre e per nós donets e asignets e o per missatge de vestra cord donar e asignar façats a. $n$ Berthomeu Ager, texidor, vostre vehi, $X$ dies de man in forma solita et cum omnibus suis asuetis, dins los quals haja donats e pagats al dit requirent en lo dit nom sexanta-cinch sous de reals de València, e són per rahó e causa de tintes de un vinthihú vert scur que aquell li teny $i^{34}$.

33. Es importante destacar que el $38 \%$ de estas deudas por productos agrícolas son por ventas de aceite, y dada la importancia de éste en el proceso de producción del paño, podría considerarse en parte como el testimonio de la distribución de una materia prima más de la manufactura textil, aunque lo hemos incluido en el grupo de deudas de origen agrícola.

34. AMC, 47 / 1, CJ, 1479-V-6. La elección del ejemplo no es casual, supone un testimonio de la potencialidad textil contestana que, con mucha frecuencia, tintaba y elaboraba paños a artesanos de otras villas. La repetición de este tipo de relaciones -como exponemos en otros ejemplos posteriores, y también documentadas con asiduidad en las fuentes notariales- nos hace pensar en el carácter central de Cocentaina en el distrito pañero que se fue configurando a lo largo del siglo XV en las comarcas interiores de la Vall d'Albaida, l'Alcoià y el Comtat, con otras villas de clara vocación pañera como 
A su vez, en los libros aparecen también copias de algunas misivas enviadas a la capital del Comtat por justicias de otras villas o ciudades (reclamando también el pago de deudas a vecinos de Cocentaina) ${ }^{35}$. Ambos conjuntos, como veremos a continuación, nos permiten una reconstrucción de los mercados asociados a la producción textil contestana: el mercado de adquisición de materias primas (lana, productos tintóreos), el mercado hacia donde se distribuían los paños contestanos (que, gracias a estas cartas, podemos fijar en el amplio conjunto de las comarcas del sur valenciano, de Xàtiva a Elx, y de Pego a Aiora), e incluso los límites del mercado de capitales -a través del crédito censal- hacia el que los poderosos artesanos y drapers emprendedores contestanos extendían su influencia ${ }^{36}$.

En ocasiones, todo el proceso judicial concluía con la tramitación de un expediente de embargo de bienes para saldar la deuda indicada. El corredor o missatger acudía a la casa del deudor para hacer un listado de posibles bienes a embargar y establecer su valor. Estas visitas a los espacios privados del ámbito doméstico con sus inventarios, nos permiten en ocasiones conocer los talleres artesanales, las herramientas y materias utilizadas, junto a todo tipo de productos almacenados en distintas estancias o "botigas" : En aprés anà a la casa del dit n'Anthoni Sanç [el pelaire vecino de Cocentaina antes citado] e feu fer scripció e anotació dels béns en la dita casa atrobats, los quals són: primo una càrrega de pastell, ítem un

Ontinyent, Alcoi, Albaida o Bocairent. Para más información sobre la relación y jerarquía establecida en esta zona manufacturera, J.A. LLIBRER. "La configuració d'un districte industrial a la baixa Edad Mitjana. Les viles draperes de la Vall d'Albaida, 1'Alcoià i el Comtat", Recerques 64 (en prensa).

35. Tipológicamente, la copia de estas cartas enviadas por otros justicias sigue la misma estructura que las anteriores. Veamos también un ejemplo significativo en el que un ciudadano de Valencia reclama una elevada deuda de pastel a un pelaire contestano: El Luís Ferrer, cavaller conseller e coper del lochtinent general governador del regne de València, a l'amat lo justícia de la vila de Cocentaina o a son lochtinent, saluts e delició. Com per altra letra nostra [...] sia estat manat a.n Anthoni Sanç, vehí vostre, que dins $X$ dies següents e perentòriament agués (sic.) donat e pagat a·n Galcerà Cepello, XXXVI lliures X sous, de deute principal de preu de cert pastel que d'aquel havia comprat, hagut e rebut [...], per ço lo dit proposant, nos ha request que ab letra nostra vos sia manat vos encautasen de la pesona de aquel [...], vos diem e manam que en continent, vista la present carta, façats scriure e anotar tots los béns mobles e semovents del dit deutor. AMC, 47 / 2, CJ, 1481-IV-9. En este caso, por la elevada cuantía de la deuda, se exige embargo de bienes del deudor.

36. De nuevo, unos pocos ejemplos ilustrativos: Nicolau Calbet, Justicia de Cocentaina, envía carta el de Alcoi para que obligue a Pere Arcaina a pagar 8 libras a Francesc Graso, tintorero contestano, por una carga de pastel que le compró (1471-VI-28); otra carta enviada al Justicia de Alcoi exige a Joan Ager, pelaire, y a Bartomeu Ager, tejedor, hermanos de la capital de l'Alcoià, que paguen 63 sueldos (restantes de 12 libras) a Joan Valls, de Cocentaina, por ciertos paños que les vendió (1472VIII-3); en una carta enviada al Justicia de Albaida encontramos una reclamación de Bartomeu Maiques, draper de Cocentaina, a Pere Arbuxec, pelaire de Albaida, que le debe 100 sueldos (restantes de aquellos 490) por tintes que li havia fetes en certs draps (1478-III-3); sólo semanas después, el Justicia contestano envía carta al de Penáguila para exigir que Joan de Bellolms, sastre de esa villa, pague a Bernat Martí, pelaire de Cocentaina, 24 sueldos y 9 dineros per rahó de tintes que li havia fetes (1478V-25); en otra misiva se obliga a na Betriu, drapera de Albayda, a pagar 195 sueldos a Andreu Buera, pelaire contestano, por una palmella 21 na verde clara que le compró (1478-XI-12); en carta enviada de nuevo a Albaida se exige a Salvador Andani, pelaire de esa villa, que pague 7 libras y 9 sueldos a Jaume Moltó, pañero contestano, por un paño 18no negro y 7 alnas de palmella azul (1481-V-10); en misiva dirigida al Justicia de Ontinyent se reclama a Joan Garcia, pelaire de dicha villa, 17 libras que debe a Joan Sancholí, pelaire contestano, per rehó de tintes (1481-VIII-21). 
sach de alum, item una arova de roga, item un matalaf reyal. E noresmenys foren stimats los altres béns de la dita casa ultra los desús scrits, per lo dit corredor de la cort e per en Francesch Fitor [pelaire contestano], los quals stimaren valer dotze lliures $^{37}$. Como puede observarse en este ejemplo, la cuantía de las deudas que aparecen en este segundo bloque documental son mucho más elevadas que las del anterior: van desde una veintena de sueldos (generalmente por pensiones de censal) hasta los 1.700, siendo también los productos textiles los que nos ofrecen las mayores cantidades. De hecho, la suma extrema de 1.700 sueldos es la que le exige el pelaire contestano Martí de Requena a su vecino, el draper Nicolau Borràs, por nueve paños que le vendió un año antes ${ }^{38}$.

Pero para poder apreciar con toda su extensión la importancia que este segundo grupo de registros judiciales tiene para el estudio del desarrollo textil, analicemos con mayor detalle los tipos de deuda que en ellos aparecen. En el Cuadro I exponemos porcentualmente las causas que generaron las misivas que envió el Justicia contestano a otros colegas: más del $40 \%$ (exactamente el 42,85\%) tienen como origen el impago de pensiones de censal. Podríamos pensar que este dato se aleja de nuestro estudio de la manufactura pañera, pero debemos indicar que los acreedores que aparecen reclamando estas deudas son siempre artesanos, drapers o mercaderes vecinos de Cocentaina. Esto nos confirma con claridad el papel del colectivo textil de la villa en este importante mercado de capitales, su capacidad de inversión y su fiabilidad, además de mostrarnos la amplitud de este mercado censalista contestano que se extendía a todas las comarcas del sur de país: muchos agricultores o artesanos de zonas alejadas a la capital del Comtat, como Vila Joiosa, Corbera, Pego, Dénia, Xixona, Bocairent, Castalla o Elx, acudían al sector artesanal y mercantil contestano para conseguir dinero líquido, como también lo hacían lógicamente vecinos de zonas más cercanas como Alcoi, Penàguila, Planes...

La segunda causa que propicia el envío de cartas es la deuda de paños (que supone el $25,71 \%$ de las misivas documentadas) y que, junto a las cartas que reclaman deudas por productos para el tinte o por el mismo proceso de tintado (el $8,57 \%$ ), nos confirma de nuevo el desarrollo textil contestano y su nivel de

37. AMC, CJ, 47/2 1481-IV-9. Este embargo se realiza por una deuda ya citada de 36 libras, que era el resto de un precio mayor de pastel que Antoni compró a Galcerà Cepello, mercader de Gandía; dos años más tarde se procede a subastar algunos de sus bienes para pagar la deuda, entre los que de nuevo encontramos productos para el tinte y algún instrumento de trabajo: Primo foren venuts dos costalls de pastell a.n Bernat Ripol per set lliures, que foren dotze aroves e set lliures. Item, foren venudes tres aroves e vint set lliures d'alum a·n Jacme Moltó a VI sous arova. Suma XXIII sous V diners. Item, fon venut un torn de filar llana a $\cdot n$ Joan de Calatayu per 3 sous. Item, fon venut a $n$ Joan de Calatayu, una poqueta de gauda per dos sous huyt diners (AMC, Cort de Justícia 47/2, 1483-IX-24). Gracias a nuestros análisis prosopográficos sabemos que todos estos compradores eran activos pelaires contestanos, lo que nos remite de nuevo a la figura del artesano emprendedor que tiende a gestionar buena parte del proceso productivo del paño, incluidas las trascendentales fases de acabado.

38. AMC, CJ 45/1, 1471-XI-26. El dato de una venta de nueve paños nos permite acercanos al nivel de producción de algunos dinámicos artesanos de la villa-como es el propio Martí de Requena-, que contaban con empresas de mayor capacidad de producción, frente a la de otros artesanos más humildes que en ocasiones se veían obligados a trabajar bajo encargo de los emprendedores (como hemos visto con las anteriores deudas de operaciones textiles). 
especialización. Los lugares de destino de estas cartas "textiles" (Biar, Ontinyent, Albaida, Penàguila y, sobre todo, Alcoi) tienden a indicarnos el papel de privilegio (¿centro rector?) de la capital del Comtat en este gran distrito artesanal que se estaba configurando en las comarcas de la Vall d'Albaida, l'Alcoià y Comtat durante el siglo XV. Otras tres cifras parecen constatar la idea anterior: en primer lugar el $11,42 \%$ de las cartas enviadas por deudas de ganado (lanar y de otros tipos), que manifiestan la potencialidad ganadera de los sectores de la villa (grandes artesanos emprendedores que son propietarios de grandes cabañas para garantizarse un suministro regular de lana, y el importante papel que en este mercado ganadero juega el colectivo mudéjar contestano) ${ }^{39}$; en segundo lugar las escasas cartas que tienen como motivo deudas por productos agrícolas (sólo el 2,85\%), parecen informarnos del cada vez mayor peso que adquirían en la villa las actividades textiles frente a las agrarias. A su vez, las pocas misivas enviadas para reclamar el impago de lana (sólo 1,42 \%) y, por el contrario, las recibidas por el Justicia contestano para exigir el pago de esta fibra textil a artesanos de la villa (el 23,52\%), nos permiten acercarnos a la estructura de la balanza comercial de Cocentaina, que importaba lana de localidades vecinas y, a su vez, redistribuía paños en este mismo amplio mercado de las comarcas del sur valenciano.

Causas de las cartas enviadas por el justicia de Cocentaina (1470-1492)

\begin{tabular}{|l|c|}
\hline \multicolumn{1}{|c|}{ CAUSAS DE LAS CARTAS } & $\%$ \\
\hline Deudas por pensiones de censal & 42,85 \\
\hline Deudas por paños & 25,71 \\
\hline Deudas por ganado & 11,42 \\
\hline Deudas por tintes o tintado de paños & 8,57 \\
\hline Deudas por productos agrícolas & 2,85 \\
\hline Deudas por lana & 1,42 \\
\hline Otros & 2,85 \\
\hline Deudas sin especificar & 4,33 \\
\hline
\end{tabular}

39. La documentación judicial es también abundante en este aspecto mostrándonos la acción de los grandes rebaños de estos artesanos y mercaderes más dinámicos: sólo en el año 1472, los escribanos del Justicia anotan en diversos asientos que los pelaires contestanos Jaume Siurana y Joan Buera, eran propietarios de una cabaña de 413 cabezas; Bernat Figuerola, otro destacado pelaire de Cocentaina, tenía unas 300 cabezas; y el importante pañero Bartomeu Maiques poseía una cabaña de algo más del millar de unidades; otros poderosos propietarios eran los pañeros Joan Pérez de Requena, Bernat d'Estanya, Nicolau Borràs, Pere Cebrià o Bernat Cirera. Por otro lado, el colectivo musulmán de la misma villa actuaba con frecuencia como mantenedor de una parte de las cabañas propiedad de la élite artesanal contestana. Sobre el mercado de lana y ganado, J.A. LLIBRER. Industria textil y desarrollo regional..., vol. I, pp. 354-405. Y sobre el papel del grupo musulmán, J.A. LLIBRER. "L'aljama com a espai econòmic: mercaders i artesans mudèjars en l'àmbit contestà", Els musulmans al Comtat, Alacant, 2009, pp. 205-221. 
Un análisis de las villas de destino de las misivas nos permite dibujar este amplio mercado de paños contestanos que se confirma mediante las compraventas y reconocimientos de deuda localizados en los protocolos notariales ${ }^{40}$. La gran cantidad de villas de destino ( 24 en total), y las relaciones que con ellas se establece, nos permiten configurar distintos niveles o radios de acción en esta amplia área de influencia hacia la que Cocentaina (o mejor, su colectivo artesano-mercantil) extendía sus intereses: el más cercano es lógicamente el formado por la propia comarca del Comtat (Penàgila y Planes reciben el 18,57 \% de las cartas) y l'Alcoià (Biar, Castalla y, sobre todo, Alcoi, que es el destino que más se repite conformando en solitario el $21 \%$ de las misivas enviadas), a la distancia de unos $15-20 \mathrm{~km}$ de nuestra villa. Las relaciones con Alcoi son especialmente significativas porque se trata de otra de las villas pañeras que se va consolidando en este distrito manufacturero, y hacia la que circulan lanas, paños, tintes contestanos ${ }^{41}$. Una segunda área de influencia es la formada por centros de las comarcas de la Vall d'Albaida y las Marinas, a unos 20-40 km: aquí destaca Vila Joiosa (8,57 \%), Ontinyent, Albaida y Bocairent (estas últimas, también con importantes comunidades textiles, concentran en total más del $20 \%$ de las misivas). Pego y Dénia se configuran como los límites costeros del mercado contestano, mientras que por el sur, y dentro ya de un tercer radio de acción que sobrepasa los $50 \mathrm{~km}$ desde Cocentaina, las villas de Xixona y Elx (más del 10\% de las cartas) suponen los extremos. Por el norte, unas pocas cartas enviadas a Xàtiva o Sueca delimitan la amplitud septentrional del mercado contestano. Todos estas villas o ciudades y estas distancias no hacen sino confirmar la potencialidad y la importancia económica de Cocentaina o, como indicábamos antes, de su sector artesano-mercantil, de sus grandes pelaires, pañeros y mercaderes que extendieron sus negocios muchos kilómetros más allá de los muros de su pequeña ciudad, que buscaban en aquellos centros lanas de distintos tipos para sus empresas, y clientes para sus paños.

Por otra parte, un análisis de las cartas recibidas por el Justicia de Cocentaina, ratifica las ideas anteriores: el $41 \%$ de las misivas son enviadas por el Justicia de Alcoi, y reclaman deudas de ganado o paños a partes iguales; por detrás, a mucha distancia, las cartas de la Vall d'Albaida (en total 23,5\%), de Xixona o unas pocas de Murcia y Chinchilla (importantes centros laneros). Más de la mitad de todas ellas (exactamente el 52,94\%) son para reclamar deudas de lana o ganado a los vecinos de Cocentaina, lo que nos informa de la amplia zona donde se abastecían de materia prima los pelaires contestanos. Por el contrario no hay ni una sola misiva que reclame el tintado de paños o productos tintóreos, lo que parece indicar la centralización (y especialización) de estas operaciones en la capital del Comtat ${ }^{42}$.

40. Sobre esta información notarial, vid. J.A. LLIBRER. Industria textil y desarrollo regional..., vol. I, pp. 647-663.

41. Sobre la comunidad pañera de Alcoi, L. TORRÓ. "Sobre la proto-industrialització. Reflexions a partir d'un cas local: Alcoi (segles XVI-XIX)", Afers 19 (1994), pp. 659-680; y del mismo autor, La Reial Fàbrica de Draps d'Alcoi. Ordenances gremials (segles XVI-XVIII), Alcoi, 1996. También A. J. MIRA. Entre la renta y el impuesto. Fiscalidad, finanzas y crecimiento económico en las villas reales del sur valenciano (siglos XIV-XVI). Valencia, PUV, 2005, esp. pp. 68-94.

42. Sobre este punto, J.A. LLIBRER. "La formación de compañías..., pp. 59-72. 
A su vez, la ausencia de cartas por impago de pensiones censalistas nos confirma que en Cocentaina se concentraba un importante grupo de acreedores de la zona -que eran, como ya hemos visto, sus grandes artesanos y pañeros-, cuya capacidad de inversión y dominio en el mercado de capitales era amplia.

En definitiva, esta segunda serie de la documentación del Justicia nos ha permitido ya trazar un primer dibujo de la potencia industrial de la villa y de su amplio mercado, a la vez que nos ha acercado al conocimiento de un conjunto de artesanos emprendedores con un volumen de negocio y actividad mayor, con empresas más diversificadas que se encargaban del aprovisionamiento de materias primas, que participaban del tintado de paños, que prestaban capital a sus vecinos y a gentes de otras villas, que se encargaban incluso de la venta directa de sus paños. Un colectivo de artesanos que, como veremos, estaba en condiciones de coordinar o gestionar buena parte del amplio proceso de producción del paño con las numerosas operaciones que éste implicaba.

\section{3. "Clams, bans, calònies e emoluments"}

El tercer bloque de registros presente en los volúmenes del Justicia de Cocentaina es el formado por el conjunto de breves acusaciones realizadas por los vigilantes municipales y guardias de la huerta y término de la villa o por los propios vecinos. Su carácter temático es marcadamente agrícola (aparecen las típicas denuncias por invasión de ganado, alteración de sembrados, robos de cultivos o frutales) pero no por ello supone un menor interés para nuestro análisis artesanal. De hecho aparecen con frecuencia los propios artesanos denunciando los robos en sus propiedades rurales, o los artesanos y drapers acusados por la circulación incontrolada de sus amplias cabañas de ganado lanar por el término. A su vez, estos registros nos permiten descubrir mano de obra auxiliar de la manufactura textil contestana porque con frecuencia los mozos o jóvenes aprendices de los talleres locales son denunciados por diversas causas, generalmente hurtos de productos agrícolas o de materias artesanales.

La tipología documental de estos breves ítems, de no más de tres o cuatro líneas, es siempre la misma: el demandante, la presunta persona afectada, o uno de los guardias de la villa, acusa, acusa ban, del infractor, y con frecuencia aporta algún testigo del delito: En Johan Delesques, guàrdia de Muro, posa clam del fill d'en Lobregat, perayre, per ço com diu que divendres propassat atrobà aquell en la morera de la mesquita del dit loch, que collia fulla ${ }^{43}$. Descrita la acusación o el delito, a continuación se consigna, escrito por otra mano -lo que indica que se redacta con posterioridad- la multa que impuso el Justicia y que ahora ha cobrado: rebé lo justícia, a part de senyor feta gràcia, I sou. La cuantía de las multas impuestas por este tipo de delitos es baja, y depende lógicamente de los daños causados al demandante o del valor de los bienes robados: se sitúa entre los 6 sueldos,

43. AMC, CJ, 47/1, 1479-II-15. 
como cifra máxima, y un dinero, como valor más bajo. Y de nuevo aquí los valores más elevados se relacionan con asuntos textiles.

Aunque estos registros parezcan referir únicamente a la estructura agraria contestana, una lectura atenta de las anotaciones refleja también con claridad la consolidación de la manufactura textil, y la cada vez mayor importancia que ésta tenía en su economía. El conflicto cotidiano entre propietarios de tierra y de grandes cabañas de ganado no era sino un aspecto más, y no poco importante, del punto anterior. El crecimiento de la cabaña contestana hacía que los espacios acotados de pasto -bovalars, deveses- resultaran insuficientes, lo que generaba constantes invasiones de parcelas y destrozos en cultivos, arbustos y frutales. Lógicamente, no todas las cabañas eran de ganado lanar, pero el hecho de que en prácticamente todos los casos, los propietarios de ganado acusados fueran artesanos, pañeros o mercaderes locales, y de que su número de cabezas fuese elevado (superando siempre el centenar), nos habla de su claro interés ganadero para garantizar y controlar el abastecimiento de la materia prima básica, la lana, aunque también de pieles, cueros y carne ${ }^{44}$.

El difícil equilibrio entre la actividad ganadera (asociada a la manufactura pañera) y el trabajo de la tierra es algo que ya comenzó décadas atrás. Como ya vimos, en los libros del Justicia del siglo XIV se incluían algunas ordenanzas que pretendían regular el uso de los espacios periurbanos para estos dos sectores: en aquel momento, segunda mitad del trescientos, los miembros de la oligarquía que controlaban los cargos municipales promulgaron numerosos establiments para compatibilizar e integrar el crecimiento ganadero con las actividades agrícolas; de hecho, el crecimiento de la manufactura, que exigía ya grandes cantidades de lana, hizo que el objetivo de estas ordenanzas fuese precisamente no poner en peligro el desarrollo de la actividades ganaderas para así no frenar un crecimiento de la producción de paños que comenzaba en esas décadas ${ }^{45}$.

44. Siguiendo algunos casos ya citados más arriba, sólo unos pocos ejemplos para ilustrar la idea. Todos han sido documentados en el volumen de 1472, y únicamente en tres meses, entre el 6 de junio y el 5 de septiembre, lo que nos indica su frecuencia: En lo mateix dia lo dit guàrdia posa clam del honrat en Berthomeu Mayques, draper, per ço com dix que anit vespre atrobà lo bestiar de aquell en lo bovalar de la dita vila e que podien ésser pus de mil cabeçes e més (1472-VI-6); Azmet Affif, moro del loch de Fraga, acusa ban a·n Bernat Figuerola [pelaire], fill de Guillem, per ço com dix que ahir trobà les cabres, ovelles e moltons de aquell en la sua heretat que té a Terratge, e han fet mallada; En Berthomeu Pérez, menor, vehín de la vila de Cocentayna, en lo dit dia posa clam del bestiar d'en Berant Figuerola [el pelaire anterior] per ço com dix que lo diluns passat atrobà aquells en lo figueral que ell té en la partida dels Sequans; en lo mateix dia Ayet Alazí, moro de la moreria, posa clam d'en Pere Martí [molinero] e de Bernat Techa [pelaire] per ço com dix que atrobà dos porchs de aquells en la sua heretat (los tres de 1472-VII-1); En Johan Monyino possa clam d'en Bernat Figuerola, carnicer de la moreria, per ço com diluns propassat LXXXX moltons, pochs més o menys, d'aquell, trobà en lo seu hort e garrofer de la horta, e juran (1472-VIII-13); En Pere Garcia, guàrdia, acusa ban a·n Bernat Figuerola [de nuevo el mismo pelaire], per ço com CCC moltons de aquell, dijous propassat los trobà en lo bovalar; en lo dit dia, lo dit guàrdia, acusa ban al dit en Figuerola per ço com los dits moltons ahir atrobà en lo guaret de la viuda muller quondam d'en Jacme Pujaçons, que té en Algar (1472-IX-5).

45. Vid. J.A. ALABAU. "Els establiment locals...", pp. 177-180. El autor documenta diversos establiments que permiten la entrada y circulación de ganado lanar en diferentes partidas del término de Cocentaina. Finalmente, a partir de 1373 la oligarquía contestana permitió la entrada en todo el 
Los conflictos entre agricultores y ganaderos no son exclusivos de Cocentaina, son frecuentes prácticamente en todas las villas valencianas bajomedievales, lo que caracteriza al caso contestano es que aquí el enfrentamiento no es entre agricultores y ganaderos, dentro de la misma franja y del mismo sector económico, sino entre intereses agrícolas e intereses artesanales, por el hecho que los propietarios de las grandes cabañas eran siempre artesanos o drapers contestanos cuya tenencia sustentava el desarrollo textil local. Pensemos que en las acusaciones por invasión o destrozos de cosechas documentadas en los diferentes libros del Justicia, el $65 \%$ de los propietarios de las cabañas ganaderas causantes son pelaires, pañeros o mercaderes locales. Así, estos activos artesanos o drapers, que eran propietarios de grandes partidas de ganado -como ya hemos visto, de centenares y hasta el millar de cabezas - intentaban una estrategia de control del espacio agrario periurbano para facilitar la gestión de sus rebaños (y atender a la demanda local de lana o carne), estrategia que lógicamente no estuvo exenta de problemas, como muestran estas anotaciones del Justicia.

Por otro lado, algunas denuncias reflejan aspectos clave de la organización productiva de la manufactura textil que no conoceríamos sin estos registros (o los conoceríamos con mucho menor detalle), por ejemplo, los amplios datos referidos a la mano de obra auxiliar, al amplio conjunto de mozos o aprendices que trabajaban junto a los artesanos propietarios de los talleres. Una mano de obra poco visible y que ahora nos aparece gracias a las denuncias por sus robos o fechorías en parcelas y campos. Todos los años, los libros del Justicia contienen al menos una partida de anotaciones sobre estos delitos menores y sus protagonistas, los jóvenes mozos adscritos al taller de algún artesano, como nos informa la propia fuente: En Jaume Garcia, guàrdia de l'Alcúdia, posa clam del moço de Francesc lo tintorer, per ço com diu que ahir atrobà aquell en les figueres de Berendi, que colia figues. En ocasiones descubrimos incluso que algunos artesanos cuentan con más de un mozo: En Johan Ramon, guàrdia de Muro, posa clam de Carbonel, moço d'en Guillem Ferrer [pelaire contestano], per ço com diu que la vespra de Sanct Johan atrobà aquell que colie peres. Item, el mateix posa clam de altre moço d'en Guillem Ferrer, per la dita rahó. Item, el mateix posa clam del fill de Bernat Ferrer [tundidor contestano], per la dita rahó. Item, el mateix posa clam de Johan, moço d'en Johan Cebrià [sastre vecino de Cocentaina], per la dita rahó. Item, el mateix posa clam del moço d'en Bernat Cirera [mercader contestano], per la dita rahó ${ }^{46}$. Estos registros nos descubren, en primer lugar, la frecuente presencia de estos trabajadores en los obradores de pelaires, tundidores, sastres o en las mismas tintorerías locales, mozos que eran contratados generalmente sin mediar contrato notarial, como comentábamos antes; pero además, estas breves anotaciones en los

término, dins los plantats de tot el terme de la dita vila, ço és, vinyes, olivars e figuerals, de partidas de ganado lanar de menos de cien cabezas, que antes de esa fecha tenían vetado el acceso. En caso de superar esa cifra de cabezas, se establecía una pena -relativamente baja- de entre 20 y 60 sueldos. Los intereses del sector artesanal local parecían imponerse ya en la villa, en un intento de fomentar su vocación pañera.

46. Todos los registros corresponden únicamente al año 1479, AMC, CJ, 47/1. 
libros del Justicia nos hablan también del nivel productivo de muchas empresas textiles contestanas que exigían ya mayor número de efectivos, de trabajadores, más allá de los que la propia unidad familiar podía aportar, para hacer frente a una demanda exterior en constante aumento. En efecto, sólo una producción para el mercado explica esta frecuente presencia de mano de obra ajena. Finalmente, esta fuente nos descubre además cuál sería la vía formativa de los oficios en estas villas sin unas normativas concretas como se habían establecido en los grandes centros urbanos.

Junto a las denuncias que nos muestran aspectos clave de la mano de obra en la manufactura contestana, debemos destacar las que refieren a algunos procesos de producción de alta trascendencia, como los destinados a la refinición del paño, es decir, aquellos que tienen como finalidad aumentar la calidad y el carácter merceológico del tejido: el abatanado y el tintado. En efecto, algunas de las denuncias remiten a robos en los molinos pañeros -como la que ofrecíamos al principio de este artículo-, o a hurtos de materias primas tintóreas de alto precio. De nuevo la fuente se convierte en testimonio directo de unas formas productivas y de su nivel de especialización.

En este sentido, en 1476 descubrimos una denuncia muy interesante: Francesc Ripoll, pelaire y guardia del término, acusa al mozo de Pere Vilar, pelaire vecino, porque lo encontró cavando "tierra de pelaires": posa clam del moço d'en Pere Vilar, per ço com diu que en lo dia de huy es stat atrobat en la sua riba que cavava terra de perayres la qual és vedada ${ }^{47}$. Por esta denuncia Pere Vilar pagó 5 dineros de multa, cifra elevada en esta sección de registros. Esta denominación de terra de perayres refiere a la greda, la arcilla que se utilizaba como producto desengrasante para la limpieza final del paño, y lógicamente al espacio reservado de donde era extraída. El hecho de que los protagonistas sean pelaires no es casual, nos testimonia la importancia del sector de la pelairía local, como veremos después, en el desarrollo y la gestión -incluso el control-de estas fases finales de la producción pañera.

Otro clam, éste de 1478, nos permite conocer un punto clave sobre la organización del proceso de la tintura, y en esencia sobre la gestión de éste por parte también de los pelaires, que se nos muestran como auténticos artesanos emprendedores que tienden a coordinar distintos procesos productivos: el 2 de marzo de 1478, el pelaire contestano Pere Cebrià acusó a tres mozos de otros tres pelaires de la misma villa porque le habían despedazado los arbustos de pastel de su huerto y le habían robado las plantas: En Pere Cebrià, perayre, posa clam del moço de Johan Margarit e del moço d'en Johan Calatayú e del moço d'en Johan Bosch, per ço com diu que en lo dia de ahir atrobà aquells en lo seu ort e li han trenquat lo pastell e furtats los brots ${ }^{48}$. La presencia de esta planta y, sobre todo, el interés de los pelaires por su cultivo directo y su posesión (no es casual tampoco que los tres ladrones sean trabajadores de otros tres pelaires), nos remite, como indicábamos

47. AMC, CJ, 46/1, 1476-XI-18.

48. AMC, CJ, 46/2, 1478-III-2. 
antes, al papel rector de estos poderosos artesanos, que tendían a coordinar todo el proceso mediante el suministro de las materias primas (lanas, tintes) a otros artesanos "dependientes" o semidependientes que en sus talleres domésticos trabajaban por encargo a cambio -como también lo indican las frecuentes denuncias ante el Justicia- de unas cantidades en metálico previamente acordadas.

\section{El teStimonio DE UNAS FORMAS DE ORGANIZACIÓN}

En definitiva, ¿qué nos testimonian y nos muestran todos los ejemplos citados? ¿Qué podemos deducir de esta información de los libros del Justicia? ¿A qué conclusiones nos acercan en relación a las formas de organización de la producción textil?

En primer lugar, estas fuentes nos permiten reconocer cómo la amplia comunidad artesanal contestana -recordemos que los análisis prosopográficos nos hablan de casi 400 artesanos en esta cronología- había llegado ya durante la segunda mitad del siglo XV a un proceso de jerarquización interna mediante la diferenciación de un grupo destacado de artesanos (pelaires, en concreto, que con frecuencia se convertirán en pañeros, y que circulan constantemente por estas páginas de la corte judicial municipal), artesanos que con mayor actividad y volumen de negocio acabaron controlando la adquisición de materias primas, junto a la gestión de las fases finales de refinición del paño, y su misma comercialización en los mercados de esta región sur del reino; frente a esta pequeña élite (que conformaba sólo un $12-15 \%$ ), el resto de unidades artesanales se muestran como más modestas, con menor capitalización y menor volumen de actividad y negocio, y además con escaso contacto directo con el mercado; también estos aparecen en los libros del Justicia, y son fácilmente identificables por sus deudas y sus relaciones laborales con los más poderosos. Así, esta apreciación sobre las diferencias entre las distintas empresas artesanales no nace de la subjetividad o de indicios documentales poco sólidos sino que son los propios análisis prosopográficos que hemos desarrollado (combinando fuentes de distinto origen, entre ellas la judicial), los que nos demuestran una mayor capacidad de producción, una más alta capitalización y un conocimiento del mercado que no poseían el resto de los miembros de la comunidad artesanal.

Hemos comprobado cómo la documentación judicial -junto a la notarial, y a las prosopografías que de ambas de derivan- nos indica que muchos de estos pequeños y humildes artesanos trabajaban -con una frecuencia que no podemos conocer- para los emprendedores en condiciones de dependencia o semidependencia, y en una situación cercana a la asalarización a través del trabajo por encargo dado que, según aportan las mismas anotaciones del Justicia, recibían ciertas cantidades en metálico a cambio de la realización de determinadas operaciones textiles.

La lectura atenta y detallada de estas denuncias por trabajo textil antes expuestas, no parece dejar lugar a dudas: en todas ellas econtramos siempre, por una 
parte, un artesano modesto (según nos indica su escasa y limitada prosopografía) que tras haber realizado una operación textil (el tejido de un paño, su tundido, su tintado o su confección) para un artesano emprendedor (como así podemos también confirmar a través de sus amplias prosopografías), reconoce que éste último no le ha pagado parte o el total de la cantidad previamente estipulada entre ambos. Estos activos artesanos son siempre pelaires o pelaires convertidos en drapers, es decir, artesanos que con el paso de los años han acabado redirigiendo o evolucionando su negocio hacia la esfera mercantil, hacia la comercialización, y no sólo de los paños, sino también de materias primas -lana, aceite, productos tintóreos-, o de ciertos productos agrícolas como cereales, vino, ganado, o incluso de capitales, a través del flujo en metálico que, mediante el crédito censal, hacían llegar a sus vecinos o a habitantes de otras villas ${ }^{49}$.

Pensemos además que la presencia de estas interesantes denuncias en los registros judiciales no es sino la confirmación de que tales relaciones de producción debían ser frecuentes en la comunidad artesanal contestana: no olvidemos que al tribunal del Justicia local sólo llegaban aquellas operaciones que habían generado algún problema por el impago de los salarios; sin embargo, su número sería mucho mayor dado que tales acuerdos de trabajo debían realizarse entre las partes sin la mediación notarial, y gracias a la confianza mutua que una relación de vecindad facilitaba. Además, su anotación en los libros de contabilidad privados era suficiante para cualquier posterior reclamación por alguna de las partes.

Una organización laboral que, según nos indican de nuevo los mismos libros del Justicia, se completaba con un tercer sector visible de mano de obra. Se trata del conjunto de mozos o aprendices que, encuadrados en el taller de un artesano titular o un maestro, trabajaban llevando a cabo tareas propias del oficio. El estatuto de estos jóvenes dependientes era más bien difuso, pues la frontera entre el aprendizaje y la servidumbre era poco clara, incluso en los casos en que disponemos de los contratos notariales de regulación, más bien pocos si los comparamos con los numerosísimos mozos que aparecen en los registros judiciales ${ }^{50}$, éstos nos hablan

49. Los análisis prosopográficos, que se han concretado en un ajustado período cronológico (1470-1505), nos han permitido identificar con relativa facilidad ambos colectivos artesanales, gracias, por una parte, a la privilegiada conservación de un nutrido grupo de fuentes (notariales, judiciales, municipales, señoriales); y, por otra, al moderado contingente demográfico de Cocentaina, pequeña ciudad de unos 2.000-2.500 habitantes, donde es mucho más fácil la tarea de localización, identificación y seguimiento de individuos, actividades y negocios. Además, ciertos linajes o familias de pelaires acaban con frecuencia consolidándose como miembros de esta élite manufacturera. Una lectura rápida a nuestras prosopografías permite observar la capacidad productiva, la iniciativa empresarial y la diversificación en los negocios de los Bosch, Calatayud, Cebrià, Estanya, Figuerola, Martí, Moltó, Nogueroles, Pérez de Requena, Ripoll, Sanç... Aquí tenemos al conjunto de artesanos emprendedores de la industria textil contestana. Y estos son precisamente los nombres que aparecen en las acusaciones del Justicia por impago de trabajos textiles. Son también los grandes prestamistas y los que se consolidan en las magistraturas urbanas (en el mismo cargo del Justicia, en la juradería, en el Consell General). Vid. J.A. LLIBRER. Industria textil y desarrollo regional..., vol. I, pp. 610-644 y vol. II, pp. 26-302.

50. Como comentábamos antes, en el periodo que estudiamos, 1470-1505, sólo hemos documentado 16 contratos, frente a los 62 jóvenes (de ambos sexos) y 10 esclavos que han sido localizados trabajando en casa de diferentes artesanos contestanos, J.A. LLIBRER. Industria textil y desarrollo regional..., vol. I, pp. 491-519. 
más bien de una polivalencia laboral en el seno del taller y la casa del artesano ${ }^{51}$. No obstante, el hecho de que sean los artesanos o pañeros los que dispongan de estos jóvenes nos posibilita hablar de mano de obra complementaria en el taller.

La presencia de los "mozos" tiene una doble trascendencia desde el punto de vista socioproductivo: en primer lugar, era lógicamente un elemento más que marcaba el nivel y la capacidad de inversión de la empresa textil, una empresa que podía asumir y mantener esta mano de obra auxiliar; así, como veíamos antes al citar los ejemplos, estos mozos estaban asociados a los artesanos más activos (a los ya indicados Bosch, Calatayud, Cebrià, Estanya, Moltó, Pérez de Requena, Ripoll...). En segundo lugar, en una villa donde no existía una regulación sobre el período o el curriculum formativo de los distintos oficios textiles, como ocurría en las grandes ciudades con los sucesivos grados de aprendiz-oficial-maestro, tal sistema asociativo mozo/artesano se convertía en la única alternativa posible no sólo para la formación sino también para conseguir el reconocimiento necesario que en un futuro permitiera la creación de un nuevo taller, de una nueva unidad productiva. De esta forma entendemos que el término mozo, a diferencia de lo que podía ocurrir en otros ámbitos ${ }^{52}$, en esta área interior valenciana, y en estas villas artesanales -todavía sin un armazón corporativo-, podía ser sinónimo de aprendiz en grado de consecución de cierto nivel de especialización.

Gracias, pues, a la documentación judicial hemos podido deducir que la organización de la producción en la industria lanera contestana se basaba en tres elementos clave complementarios entre sí: por una parte el trabajo de un gran número de pequeños artesanos que desarrollaban en sus talleres domésticos diferentes operaciones del obraje de los paños (todas las tareas de preparación de la lana, urdido, tejido, tundido...). El trabajo desarrollado en estas pequeñas pero numerosas unidades de producción se basaba en la aportación laboral de la familia artesana. En ocasiones -en relación a los ritmos de la demanda-, estos talleres podían desarrollar una actividad cercana a la asalarización, un trabajo dependiente para los artesanos más activos y emprendedores.

En segundo lugar, otro elemento clave es la importancia que, ya desde principios del siglo XV, adquieren en la industria textil contestana, los procesos de refi-

51. Vid. P. IRADIEL. "Familia y función económica de la mujer en actividades no agrarias". La Condición de la mujer en la Edad Media. Madrid, Universidad Complutense, 1986, pp. 223-259; R. SIXTO. La contratación laboral en la Valencia medieval. Aprendizaje y servicio doméstico (14581462). Tesis de licenciatura inédita, Universitat de València, 1993; G. NAVARRO. "Aprendices textiles en la Valencia medieval. Los contratos del Padre de huérfanos Tomàs Oller (1461-1468)". Actas del II Congreso de Jóvenes Historiadores y Geógrafos, Valencia, 1993, 141-148. A. FURIÓ, A. MIRA, P. VICIANO. "L'entrada en la vida dels joves en el món rural valencià a finals de l'Edat Mitjana", Revista d'Història Medieval 5 (1994), pp. 75-106; A. FURIÓ. "Entre la complémentarité et la dépendance: rôle économique et travail des femmes et des enfants dans le monde rural valencien au bas Moyen Âge", Médiévales 30 (1996), pp. 23-34. J. APARICI. "El trabajo de los jóvenes en la Edad Media: contratos de «afermament» en Vila-real". Millars. Espai i historia 18 (1995), pp. 97-114.

52. Sobre un repaso de los significados que el término "mozo" podía adquirir en diversos espacios castellanos, vid. D. MENJOT. "Les métiers en Castille au bas Moyen Âge: approche des «vécus socio-économiques»", Les métiers au Moyen Âge. Aspects économiques et sociaux, Lovain-la-Neuve, 1994, pp. 205-227. 
nición o acabado del paño (tundido, abatanado, tintado) con una clara intención de mejorar el nivel de calidad del producto y lógicamente su carácter merceológico. No olvidemos que tales procesos productivos exigían importantes inversiones de capital fijo y circulante, y que sólo aquellos artesanos en mejores condiciones y con empresas más solventes podían afrontar ${ }^{53}$.

En tercer lugar, la marcada parcelación de todo el proceso de producción y acabado del paño, con una gran cantidad de operaciones y la necesaria participación de mano de obra con muy diferentes niveles de especialización (desde la mujer que en su casa hilaba la lana hasta el maestro tintorero que conocía las complejas técnicas de coloración del paño), fue la que con el tiempo dio lugar a la concreción de un grupo emprendedor que intentará coordinar y gestionar este dilatado proceso productivo. Así, un pequeño grupo de talleres artesanales, a causa de determinadas ventajas debidas a distintos factores (saber técnico, propiedad de un amplio patrimonio inmueble por su pertenencia a linajes destacados, participación favorable en el mercado del crédito y en el mercado de productos agrícolas), pudo diversificar y ampliar el volumen de negocio de sus empresas, acercándose ventajosamente al mercado de materias primas y al dominio de determinadas instalaciones industriales (batanes, tiradores, tintorerías, almazaras) gracias a una disponibilidad de capital que les facilitaban los numerosos negocios donde intervenían (mercado de la tierra, de productos agrícolas, del crédito censal). Sus conocimientos técnicos, junto a su capacidad de inversión, les permitió gestionar con el tiempo una mayor cantidad de operaciones del proceso productivo e incluso contratar a otros artesanos para aumentar su producción, mientras que su conocimiento de los mercados les permitió gestionar la venta de sus tejidos. Este grupo emprendedor estaba formado, como ya hemos visto, por pelaires que, en ocasiones derivaron en pañeros o drapers, auténticos "señores del paño" que con una más capitalizada gestión empresarial daban la unidad necesaria al proceso de elaboración textil: de ellos nacía la "cadena" productiva mediante la adquisición de las materias primas o con la propiedad de sus cabañas ovinas (y su venta o distribución a otros artesanos vecinos) y en ellos terminaba también todo el proceso mediante la gestión del abatanado, el tintado y la comercialización de los paños. Así, de este sector artesano emprendedor no sólo partía con frecuencia la iniciativa de fabricar el tejido, además distribuía en ocasiones la materia prima o el producto semielaborado que debía ser transformado, previo encargo, en los talleres familiares; e incluso dominaba, poseía o tomaba en arrendamiento las grandes instalaciones o infraestructuras necesarias para la producción como batanes, tintorerías o tiradores.

53. Esta tendencia es observada en los grandes centros pañeros, vid. P. IRADIEL. "Ciudades, comercio y economía artesana", XXV Semana de Estudios Medievales, Pamplona, 1999, pp. 603-658. Y más recientemente P. IRADIEL. "Métrópolis y hombres de negocios (siglos XIV y XV)", XXIX Semana de Estudios Medievales, Pamplona, 2003, pp. 277-310. Y en concreto para el caso contestano, J.A. LLIBRER. "La formación de compañías..., pp. 59-72. Sobre la gestión de sus molinos pañeros, J.A. LLIBRER. "La gestió dels batans i el desenvolupament de la indústria tèxtil al segle XV. El cas de l'àrea Alcoi-Cocentaina", Estudis d'Història Agrària 23 (2012), pp. 231-248. 
Finalmente, concluido el obraje del paño, estos mismos pelaires o drapers los ponían en circulación en los mercados de las comarcas vecinas ${ }^{54}$.

De esta forma, podemos concluir que el desarrollo de la manufactura textil contestana estuvo en relación directa a la creación y consolidación de esta "élite" artesanal que tendía a la gestión del proceso y a la realización de las inversiones necesarias para dar a la producción el nivel de calidad y acabado que exigía una amplia demanda en esta región sur del reino. Y los libros del Justicia municipal son un magnífico observatorio donde se ven todas estas estrategias del grupo emprendedor: en sus páginas vemos cómo estos activos artesanos compran lana en abundancia, o cómo son propietarios de amplias cabañas de ganado lanar; también entre estos registros les vemos vender, en grandes cantidades, aceite, cereales, vino, tintes o los mismos paños; paños que ellos mismos han encargado tejer, tundir o tintar a otros artesanos vecinos, y cuyos encargos aún se leen en estos mismos libros; también aquí les vemos asociarse mediante la formación de compañías de capital para fomentar estas actividades manufactureras de producción, venta y tintado de paños; incluso vemos con frecuencia cómo prestan dinero a sus vecinos o a habitantes de otras villas mediante el crédito censal...

En efecto, después de haber estudiado los tres tipos de registros documentales que aparecen en los volúmenes del Justicia (obligacions, cartes, clams), nos ha quedado clara la riqueza "económica" de la fuente, en concreto su utilidad para el estudio de la industria textil y para adentrarse en sus procesos y relaciones de producción. Dado que es difícil encontrar documentación municipal seriada para época medieval, y a causa también de la inexistencia todavía de normas corporativas, su interés es aún mayor porque nos puede acercar a las tendencias, a las formas de organización de la producción y a la evolución del desarrollo artesanal. En todos los registros observamos que la presencia de las actividades textiles o de los propios artesanos y pañeros es constante, también vemos cómo circulan constantemente lanas, tintes o paños. En definitiva, si los libros del Justicia son un reflejo de las actividades y los negocios de una comunidad, los datos que nos aportan nos pueden confirmar el desarrollo y el peso de la industria en su economía local.

\section{BIBLIOGRAFÍA}

ALABAU, J.A. "Els establiment locals com a instrument de control econòmic i social de les viles medievals valencianes. Cocentaina a la darreria del segle XIV”, Afers 47 (2004), pp. 175-187.

APARICI, J. "El trabajo de los jóvenes en la Edad Media: contratos de «afermament» en Vila-real". Millars. Espai i historia 18 (1995), pp. 97-114.

- Producció manufacturera i comerç a Vila-real (1360-1529). Vila-real, Ajuntament, 1996.

54. Sobre el origen, las empresas y negocios del colectivo emprendedor, vid. J. A. LLIBRER. Industria textil y desarrollo regional..., vol. I, pp. 603-670. 
- El Alto Palancia como polo de desarrollo económico en el siglo XV: el sector de la manufactura textil. Segorbe, Ajuntament, 2001.

- "Materia prima para la manufactura. Su abastecimiento en Castelló a través de las actas del Justicia (1416-1450)", Millars. Espai i història 34 (2011), pp. 23-40.

ARNOUX, M., BOTTIN, J. "Les acteurs d'un processus industriel. Drapiers et ouvriers de la draperie entre Rouen et Paris (XIV-XVI siècle)", en ARNOUX, M. y MONNET P. (dirs.) Le technicien dans la citté en Europe occidentale. 1250-1650. École Francaise de Rome, 2004, pp. 347-386.

BARRIO, J.A. "Lo marginal y lo público en Orihuela a través de la acción punitiva del Justicia Criminal, 1416-1458", Idem, pp. 81-98.

BORDES, J. Desarrollo industrial textil y artesanado en Valencia. De la conquista a la crisis (1238-1350). Valencia, Consell Econòmic i Social, 2006.

CÓRDOBA DE LA LLAVE, R. "Los batanes hidráulicos de la cuenca del Guadalquivir a fines de la Edad Media: explotación y equipamiento técnico", Anuario de Estudios Medievales 41/2 (2011), pp. 593-622. http://dx.doi.org/10.3989/ aem.2011.v41.i2.364

FERRAGUD, C. El naixement d'una vila rural valenciana. Cocentaina, $1245-$ 1304. València, PUV, 2003.

FURIÓ, A. "Entre la complémentarieté et la dépendence: rôle économique et travail des femmes et des enfants dans le monde rural valencien au bas Moyen Âge", Médiévales 30 (1996), pp. 23-34. http://dx.doi.org/10.3406/medi.1996.1349

_. "Endettement paysan et crédit dans la Péninsule Ibérique au Bas Moyen Âge", en BERTHE M. (ed.) Endettement paysan et crédit rural dans l'Europe médiévale et moderne, XVII Journées Internationales d'Histoire de l'Abbaye de Flaran, Toulouse, 1998, pp. 139-167.

-. "Crédit, endettement et justicie: prêteurs et débiteurs devant le juge dans le royaume de Valence (XIII-XV siècle)", en CLAUSTRE J. (dir.) La dette et le juge. París, 2006, pp. 19-53.

—, MIRA, A., VICIANO, P. "L'entrada en la vida dels joves en el món rural valencià a finals de l'Edat Mitjana”, Revista d'Història Medieval 5 (1994), pp. 75-106.

GARCÍA MARSILLA, J.V. Vivir a crédito en la Valencia medieval. De los orígenes del sistema censal al endeudamiento del municipio, Valencia, PUV, 2002.

GARCÍA SANZ, H. "La obligación”, Boletín de la Sociedad Castellonense de Cultura 11 (1930), pp. 22-27.

GEREMEK, B. Le salariat dans l'artisanat parisien aux XIIIe-XVe siècles. Etude sur le marché de la main d'œuvre au Moyen Age. París, Mouton, 1982 (original de 1968).

GUINOT, E. "Senyoriu i reialenc al País Valencià a les darreries de l'època medieval", Lluís de Santàngel i el seu temps, Valencia, Ajuntament, 1992, pp. 185-202. 
-. "Sobre l'activitat de la justícia a un menut poble valencià d'inicis del segle XV: Xixona (1413)", Anales de la Universidad de Alicante-Historia Medieval 10 (1995), pp. 63-80.

INSA, M.D. "La justicia municipal en el Condado de Cocentaina durante el siglo XVI: problemas jurisdiccionales”, La ciudad hispánica durante los siglos XIII-XVI. Madrid, 1985, pp. 1645-1659.

IRADIEL, P. Evolución de la industria textil castellana en los siglos XIII-XVI. Factores de desarrollo, organización y costes de la producción manufacturera en Cuenca. Salamanca, Universidad de Salamanca, 1974.

—. "Familia y función económica de la mujer en actividades no agrarias". La Condición de la mujer en la Edad Media. Madrid, Universidad Complutense, 1986, pp. 223-259.

—. "El mundo urbano. Propuestas y perspectivas de la investigación medieval", Millars. Espai i història 13 (1990), pp. 80-88.

—. "Ciudades, comercio y economía artesana", XXV Semana de Estudios Medievales, Pamplona, 1999, pp. 603-658.

- et al. Oficios artesanales y comercio en Castelló de la Plana (1371-1527). Castelló, Fundació Dávalos-Fletcher, 1995.

LALINDE ABADÍA, J. "El "Curia" o "cort”. (Una magistratura medieval mediterránea)", Anuario de Estudios Medievales 4 (1967), pp. 169-300.

LLIBRER, J.A. "La indústria tèxtil contestana al segle XV. Històries d'artesans i exercici prosopogràfic", Alberri 18 (2007), pp. 9-49.

- Los orígenes de la industria de la lana en la Baja Edad Media. Valencia, Generalitat, 2007.

—. "L'aljama com a espai econòmic: mercaders i artesans mudèjars en l'àmbit contestà", Els musulmans al Comtat, Alacant, 2009, pp. 205-221.

-. Industria textil y desarrollo regional: la Vall d'Albaida y el Comtat durante el siglo XV. Tesis doctoral inédita, Universitat de València, 2010, dirigida por Paulino Iradiel, 2 vols.

-. "La formación de compañías para el tintado de paños. El caso de Cocentaina en el siglo XV", Anuario de Estudios Medievales 41/1 (2011), pp. 59-72. http://dx.doi.org/10.3989/aem.2011.v41.i1.336

- " "La gestió dels batans i el desenvolupament de la indústria tèxtil al segle XV. El cas de l'àrea Alcoi-Cocentaina", Estudis d'Història Agrària 23 (2012), pp. 231-248.

MENJOT, D. "Les métiers en Castille au bas Moyen Âge: approche des «vécus socio-économiques»", Les métiers au Moyen Âge. Aspects économiques et sociaux, Lovain-la-Neuve, 1994, pp. 205-227.

MIRA, A.J. Entre la renta y el impuesto. Fiscalidad, finanzas y crecimiento económico en las villas reales del sur valenciano (siglos XIV-XVI). Valencia, PUV, 2005.

NARBONA, R. "El Justicia Criminal. Una corte medieval valenciana, un procedimiento judicial”, Estudis Castellonencs 3 (1986), pp. 289-310. 
- Malhechores, violencia y justicia ciudadana en la Valencia bajomedieval. Valencia, Ajuntament, 1990.

NAVARRO, G. "Aprendices textiles en la Valencia medieval. Los contratos del Padre de huérfanos Tomàs Oller (1461-1468)". Actas del II Congreso de Jóvenes Historiadores y Geógrafos, Valencia, 1993, 141-148.

—. Los orígenes de la sedería valenciana. Siglos XV-XVI. Valencia, Ajuntament, 1999.

- El despegue de la industria sedera en la Valencia del siglo XV. Valencia, Generalitat, 1992.

PÉREZ, P. El Justicia criminal de Valencia (1479-1707). Una magistratura urbana valenciana ante la consolidación del Absolutismo. Valencia, Generalitat, 1991, esp. pp. 30-64.

ROCA TRAVER, F. El Justicia de Valencia, 1238-1321. Valencia, Ajuntament, 1970.

SIXTO, R. La contratación laboral en la Valencia medieval. Aprendizaje y servicio doméstico (1458-1462). Tesis de licenciatura inédita, Universitat de València, 1993.

TORRÓ, J. La formación d'un espai feudal. Alcoi de 1245 a 1305. València, Centre d'Estudis d'Història Local, 1992.

—. "Sobre la proto-industrialització. Reflexions a partir d'un cas local: Alcoi (segles XVI-XIX)", Afers 19 (1994), pp. 659-680.

—. La Reial Fàbrica de Draps d'Alcoi. Ordenances gremials (segles XVI-XVIII), Alcoi, 1996.

Fecha de recepción del artículo: julio 2013

Fecha de aceptación y versión final: septiembre 2013 
